\title{
LINGUOCULTURAL PECULIARITIES OF GERMAN AND GEORGIAN PHRASEOLOGICAL UNITS - CONTRASTIVE ANALYSIS
}

\author{
Nana Stambolishvili \\ Faculty of Humanities \\ Batumi Shota Rustaveli State University \\ 35 Ninoshvili str., Batumi, Georgia, 6010 \\ n_stamboli@yahoo.com \\ Anzor Abuseridze \\ Faculty of Humanities \\ Batumi Shota Rustaveli State University \\ 35 Ninoshvili str., Batumi, Georgia, 6010 \\ abuseri@yahoo.com
}

\begin{abstract}
Knowledge about the world begins with gaining knowledge about the language. Language is a part of our national culture and plays one of the main roles in its formation. Unity of language, culture and thinking determines and forms not only national mentality, but national character as well. Specific features of the national identity are reflected in phraseological units.

Phraseological unit in German, as well as in Georgian language, is a complex verbal formation. Linguistic and extralinguistic factors play an importanat role in the formation and development of phraseological units. But there are still questions how are these phraseological units created and which language is the source language and which one is the target one.

Our goal is to study the origin and structure of some German phraseological units (especially idiomatic phraseology)and to find their equivalents in Georgian. We also aim at enriching idiomatic phraseologisms with the examples of their actual use in current parlance, finding their Georgian equivalents.

The present work tries to contribute to broadening the scope of investigation and methodology of the previous contrastive German-Georgian phraseology research and fill research gaps in this field.

Keywords: language, culture, national mentality, idiomatic phraseologisms, equivalents.
\end{abstract}

DOI: $10.21303 / 2504-5571.2019 .00966$

\section{Introduction}

Each language is unique not only in terms of structure but also in terms of national perspectives in it. Division of the objective world is clearly seen in lexical units. Phraseology is a part of linguistic picture of the world.

Phraseological units (also called idioms) are word-groups with the fixed lexical composition and grammatical structure. According to T. C. Cooper "An idiom can have a literal meaning, but its alternative, figurative meaning must be understood metaphorically" [1]. The grammatical form of an idiom is fixed. Its meaning, familiar to native speakers of a given language, is generally figurative and cannot be derived from the meanings of the phraseological unit's component parts.

In the early days of phraseology research, neither classification nor terminology of different researchers and research directions were compatible. As Fleisher says: "many linguists therefore speak of a terminological chaos that prevails in phraseology". Fleischer himself uses different phrases: "phraseologism", "(fixed) phrase" and "fixed verbal combinations" in the book "Phraseologie der Deutschen Gegenwartssprache" [2].

Burger also shares this point of view: "Phraseology as a relatively young linguistic subdiscipline is characterized by terminological diversity. It deals with the research of phraseologisms or idioms. These terms could be considered synonymous and are now the most widely used internationally. One can also call them fixed turns, solid word combinations / word groups [3]. 
Römer distinguishes the term "idiomatic phraseologisms". According to him "idiomatic phraseologisms are phrases in which the overall meaning can not be deduced directly from the meaning of the individual elements" [4].

Busch prefers the term "phraseologism". He defines phraseologism in this way: "Phraseologism as a syntagmatic union is a combination of two or more words that is used in the speech community much like a lexeme as a fixed connection with its own fixed meaning" [5].

We believe, that phraseologism is a neutral term for all the above mentioned terms - "All idioms belong to phraseologisms, but not all phraseologisms are idioms" [6].

Phraseological unit (idiom) is the most colourful part of the vocabulary which represents nation's peculiar vision of the world. It reflects nation's history, customs and traditions. Phraseology as a segment of the linguistic picture of the world is the result of material and spiritual culture of the nation, demonstrating peculiarities of the religious system, historical processes, folklore traditions, geographical, climatic and natural aspects, ethical and moral norms of the nation [7].

The phraseological component of the language, not only reproduces the elements and features of cultural and national outlook, but also forms them. Every idiom, containing a cultural connotation, contributes to the whole mosaic picture of the national culture.

In this work we aim at conducting a contrastive analysis of German and Georgian phraseological units and seeing similarities and differences between them. Contrastive-historical and contrastive-comparative methods enable us to find similarities and differences between phraseologisms of two different langauages. In the practical part, an attempt is made to trace the development of idiomatic phraseologisms in both German and Georgian and find equivalence relationships between languages.

\section{Methodology}

In this work we analyze phraseologisms, using the following criteria: In our article we referred to the works by H. Burger, A. Busch and O. Stenscheke, W. Fleischer, V. Vinogradov, Römers and Georgian researcher A. Takaishvili.

In order to check, whether the selected phraseologisms were included in dictionaries, we used:" Dudenverlag "Phrases Dictionary of German Idiomatics", "Sakhoia Tedo" Kartuli Khatovani sitqva tkmani”, "German-Georgian Phraseological Dictionary" and "German-Russian Phraseological Dictionary".

Methods, used by us in the following article, are: inductive and deductive methods. We also used the comparative method to find similarities and differences between the source language and the target language.

\section{Research results}

\section{1. Free Word Groups and Phraseological Units}

Words usually do not exist in isolation, but are related to each other. They form free syntactic connections. Each free syntactic phrase is a grammatically decomposable union of two or more words; Syntactic word connections can be analyzed from semantic point of view. Each component of free syntactic phrase is independent and has its own meaning. Free word connections may become rigid in their use and form, lose their real significance, and, as a result of a reinterpretation, become standing phrases; e. g. einen Faden, ein Band um den Finger wickeln (lit.wrap a thread, a ribbon around the finger) is used as a free word connection. But $j-n$ um den Finger wickeln (lit. to wrap someone around the finger)is already due to the reinterpretation of a standing word connection and means: 'to guide someone', 'lying.'

...Dieser Deutsche, er glaubt, er braucht nur hierherzukommen, und schon wird er alle Leute um den Finger wickleln. Ach, wie eingebildet und albern er ist.(B. Kellermann). (This German, he thinks he just needs to come here, and he'll wrap all the people around the finger, Oh, how conceited and silly he is).

As for characteristic features of phraseological units, following characteristics are named by Fleischer [2].Their special character as solid verbal connections results from their (semantic) 
idiomaticity and their (semantic-syntactic) stability. Related to this is their storage (lexicalization) as a lexical unit, which is reproduced in the text design.

Burger (1998) highlights polylexity, strength, and idiomaticity and Nunberg, Sag, and Wassov (1994) emphasize "conventionality, infexibility, figuration, proverbiality and affect" [3].

From the grammatical point of view, phraseologisms are phrases that are familiar to the speakers of certain languages and represent standard uses (conventionality). Like words, they are fixed components of the lexicon and have grammatical features of polylexity and lexicalization. " $A$ larger group also carries the feature the meta-communicativity" [4]. Phraseologisms in the narrower sense are often pictorial and have evaluative character. Thus they are found in oral speech.

So, phraseological units are characterized by reproducibility, stability, lexicality, and idiomaticity.Reproducibility is seen as a special ability to be a stable, historically fixed language. "die Phraseologismen werden nicht mehr nach einem syntaktischen Strukturmodell in der Äußerung produziert, sondern als fertige lexikalische Einheiten reproduziert" (phraseologisms are no longer produced, according to a syntactic structure model in the utterance, but are reproduced as readymade lexical units) [2].

Thus, phraseological units can be defined as stable word groups with a specialized meaning of the whole. The following features can be singled out from Stability.The usage of a phraseological unit is not subject to free variations, and the grammatical structure of phraseological units is also stable to a certain extent, e. g. etwas (jemanden) in der Hand halten/haben (to hold something (someone) in the hand). The term is in its proper meaning a free syntactic phrase, e. g. ein Buch in der Hand halten (holding a book in the hand). Used figuratively, it becomes a standing phrase: jemanden in der Hand halten= (lit.hold someone in your hand) =figurative meaning: "jemanden in der Gewalt haben" (to have someone in the power).

...Er hielt ihn in der Hand, er konnte ihn vernichten (H.Mann). (He held it in his hand, he could destroy it).

Stability makes phraseological units more similar to words, rather than free word combinations.

Idiomaticity. The meaning of the whole is not deducible from the sum of the meanings of the parts, e. g. "jemandem den Kopf waschen" = (lit.washing someone's head) means "not to wash someone's head", but 'jemanden tadeln' (to blame somebody). Idiomaticity is the semantic reinterpretation of individual components or of the whole phraseologism. Individual components give up their free meaning in favor of a new meaning.

Idiomaticity is also a relative feature, because it is depended on context and prior knowledge (especially if unique components occur, i. e. words that no longer have free meaning in today's language), e. g "Kohldampf schieben" (Be hungry), “jemanden ins Bockshorn jagen” (scare someone).On the other hand, it is gradually gradable, so there exist:

- Fullidiomatische Phraseologismen (expression as a whole is reinterpreted), "bei jmdm. Einen Stein im Brett haben"= (lit.Have a stone in the board $)=$ figurative meaning: jemandem sympathisch sein(be sympathetic to someone). Die Engel singen hören= (lit.the angels are singing $)=$ figurative meaning: starke Schmerzen empfinden (feel strong pain).

- Teilidiomatische Phraseologismen (only individual components are reinterpreted (phrase bound), others retain their literal meaning, e. g. "blind Passenger"= (lit. Blind passenger) = figurative meaning: Fahrgast ohne Fahrkarte (Passenger without a ticket); einen Streit vom Zaun brechen $=($ lit. to break the dispute from the fence $)=$ figurative meaning:einen Streit beginnen(to start a fight).

- Non-idiomatische Phraseologismenor collocations (the components are not reinterpreted). Beitrag leisten - beitragen (to contribute). Entscheidung treffen - entscheiden (to make decision).

In the semantic sense, a combination of words is idiomatic, when there is a difference between figurative (phraseological) and literal (free) meanings. The greater the difference between these two meanings, the greater is the idiomaticity of the phraseologism. Motivation, as an antithesis to semantic idiomaticity, means that the meaning of a phraseologism can be understood from the free meaning of the word combination or from the meanings of the components. ,The greater the motivation, the smaller the idiomaticity and vice versa" [8]. 
In addition to the above-mentioned features of idiomatic phraseologisms, there is another important feature: That's expressivity "Not a linguistic sign is expressive, but its use in a particular interaction situation" [9]. Burger also mentions "expressivity" as one of the main features of phraseologisms but uses another term "connotative surplus value" for it: "Phraseologisms have a connotative advantage over simple words or non-phraseological equivalents. Some of these are latent features that only become effective in certain contexts" [8].

It is a fact, that idiomatic phraseology is more expressive than free syntagmas. For example, idioms with the soma-center in German and Georgian languages prove that many somatic phraseological units are very expressive and impressive. Besides, somatic phraseologisms are more or less universal in meaning and have equivalents in other language. Here are examples of expressive and figurative somatic phraseology that have the same or nearly the same structural-semantic matching.

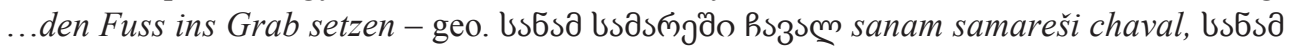
bymo doçsu sanam suli midgas; (lit. Until I go into the grave);

"Bis ich den Fuss ins Grab setzte, weißt du, werde ich mich mit Freuden an die Sommerwochen erinnern" (Th. Mann-Buddenbrooks) (Until I set foot in the grave, you know, I'll be happy to remember the summer weeks).

\section{2. Classification of Phraseological Units}

Phraseological units can be classified, according to the ways they are formed, according to the degree of the motivation of their meaning, according to their structure and according to their part-of-speech meaning.

In German Linguistics, Burger and Fleischer made the classification of phraseologisms. Fleischer made the semantic-structural classification. Burger classified phraseological units syntactically. Busch and Stenschke's classification was based on Burger's (2003) classification. They singled out ten basic classes in phraseologisms [5].

V. V. Vinogradov, a founder of the Russian phraseology tradition, worked out phraseology as a branch of linguistics. V. Vinogradov worked out a special classification of the fixed phrases of the Russian language.

V. Vinogradov distinguished three types of phraseological units: phraseological fusions, phraseological unities, phraseological collocations/combinations [10]. This classification is based on the semantic principle and therefore can be called "semantic classification". We can apply this classification to phraseological units of German language:

1. Phraseologische Zusammnebildungen (phraseological fusions). Phraseological fusions are completely non-motivated word-groups, e. g. ger. einen Affen fressen (an jm.)= (lit. eat a monkey to someone =figurative meaning: to love someone very much,or a synonym einen Narren gefressen haben (an jm. an etwas)= (lit. have eaten a fool to someone or to something= figurative meaning: to be in love with someone).

Ja, der Minister hatte sogar einen Narren an dem Harteisen gefressen (H. Fallada). (Yes, the minister had even eaten a fool on the Harteisen)

2. Phraseologische Einheiten (Phraseological unities).This group includes German phraseologisms that are clearly motivated. Semantically, they are indecomposable and, like phraseological fusions, can be considered as equivalents of words.Their overall meaning is derived from the meanings of the components. So the meaning of the whole can be explained and motivated by the meanings of the components: Stroh im Kopf haben= (lit.To have straw in one's head= figurative meaning: to be stupid); grosse Augen machen= (lit.to make big eyes= figurative meaning:be amazed; auf die Beine kommen= (lit.To get on one's feet = figurative meaning: to recover).

Sie (Frau Beate) will mir helfen, wieder auf die Beine zu kommen, die gute Seele, "dachte er" (Kellermann-Totentanz). (She (Mrs. Beate) wants to help me get back on my feet, the good soul, "he thought").

3. Phraseologische Verbindungen (phraseological collocations/combinations). In contrast to the first two groups of phraseologisms, these phraseologisms are characterized by a partial reinterpretation and complete motivation; they are usually verbal connections, in which only the verb is used metaphorically. The nominal part usually retains its real meaning, e. g. zum Ausdruck 
bringen (to express). In this word combination the verb bringen(to bring) is metaphorically reinterpreted, the noun Ausdruck (expression) retains its real meaning, but the whole thing means ausdrücken(to express). Other examples of phraseological combinations are: nicht in die Frage kommen: 'nicht wichtig sein' (do not get into the question - 'be of no importance'), in Gefahr schweben'in Gefahr sein' (floating in danger 'being in danger').

...Für Emanuel kam das nicht in Frage, er musste sich nur den Tagesstempel holen. (R. Braune). (For Emanuel that was out of the question, he just had to get the day stamp)....Was zuerst die Gafahr anlangt, in die Sie mich bringen, so habe ich mein Lebtag, seit ich im Beruf stehe, in Gefahr geschwebt (H. Fallada). (As for the danger to which you bring me first, I have endangered my life ever since I was at work).

Initially, Vinogradov considered only phraseological fusions as idioms, because phraseological unities are clearly motivated. In our opinion, figurations can not be regarded as distinctions of phraseological fusions and phraseological unities, because fusions were once figurative figments. The Georgian linguist A. Takaishvili emphasizes that it is possible to unite phraseological fusions and phraseology units: "It is a legitimate requirement to unite these two types of phraseology and call it idiom" [11].

\section{Discussion}

Each language is unique not only in terms of structure but also in terms of national perspectives in it. The division of the objective world is clearly seen in lexical units, especially in phraseology. Phraseological units are the part of the linguistic picture of the world. They not only describe the world, but interpret it, evaluate and express a subjective attitude towards it. This is the peculiarity, which differentiates idioms and metaphors from other nominative units.

Phraseological units are stable word-groups with partially or fully figurative meanings. Where does the phraseologism 'ins Gras beißen' originate from?

German phraseological unit ins Gras beißen is used with a reference to soldiers who lose their lives in the battle. In English there is a idiom "to bite the dust", which means biting into the dust. (lit. in den Staub beißen). The idea that dying warriors bite the earth has been documented since antiquity, as in the Iliad and in the Aeneid.

The phrase biting the grass occurs in German in the 17th century in the sense of "dying" (ins Gras beißen, Internet)

In phraseolgical units literal and figurative meanings are totally unrelated, for example "jemandem reinen Wein einschenken"= (lit. "to pour someone pure wine")= figurative meaning: to tell the truth.This phrase originates from Middle Ages when the landlords mixed their wine with various ingredients (for example, sulfur, acetic clay, water, etc.) and sold it as wine. (Internet).

The linguistic basis of the phraseological unit is the code that is in the hands of the addressee. The code performs the communicative function. The addressee chooses special indicators (word-symbols) by association, in order to avoid problems while coding. Names of internal and external parts of the body (heart, abdomen, neck, body, kidney, eye, hand, foot, fingers, etc.), names of professions (shoemaker, glazier), names of kinship (mother, brother), human feelings (pleasure, sorrow) and names of some unusual creatures (witch, devil) are the constituents of the microsystem, that are used as symbols and reflect human's psychological and intellectual life. Such idioms have full or partial equivalents in different languages.

"Ein Aug(e )auf jmdn. haben"= (lit. to have an eye on somebody, to put an eye on some-

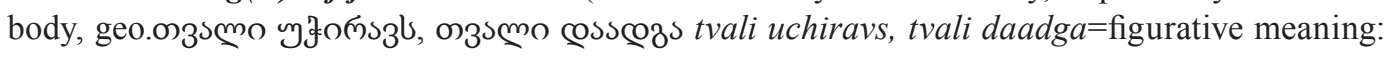
to want, to like).

"Du bist ein heimlicher Katholik... auf dich habe ich schon längst ein Auge..."(H. Mann-Henri Quatre, Jugend).(You are a secret Catholic ... I have long had an eye on you ...)”.

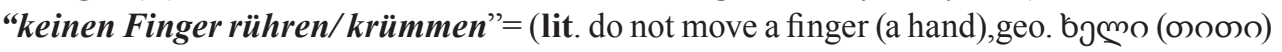
sळ зssбдпом kheli (titi) ar gaandzrio= figurative meaning: to do nothing).

Ich habe bei meinen Eltern nicht nötig gehabt, einen Finger zu rühren (Th. Mann- „Boddenbrooks") ( I did not need to move a finger with my parents). 
Semantic synthesis of a phraseological unit requires associative transformations. Associative transformations are peculiar to every language. An associative transformation means, that events, actions or properties are described indirectly, through associations.

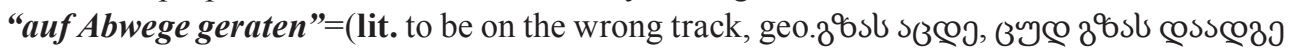
gzas atsde, tsud gzas daadge= figurative meaning: to go on the wrong course of action).

...Der eine (von den Söhnen)- und gerade der Älteste ist vollkommen auf Abwege geraten (Bredel-Verwandte und Bekannte). "He one (of the sons) - and just the oldest one is completely gone astray (missed the way)".

"sich auf dem Holzweg befinden"= (lit. to go on the wrong way; to take the wrong path,

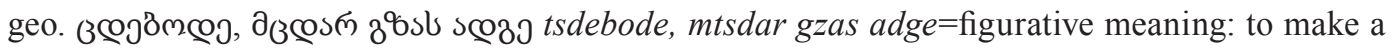
mistake while making decision).

"Wenn Sie sich etwa der Hoffnung hingehen, meiner Frau Grillen in den Kopf zu gesetzt zu haben, so befinden Sie sichauf dem Holzwege, mein wertgeschätzter Herr" "(Th. Mann-Tristan).(If you are hoping to put crickets in my wife's head, you are on the wrong track, my esteemed lord)".

The new understanding of the free phrase is one of the sources of set phrase formation. As a result of the new understanding, components of free phrases and set phrases belong to differ-

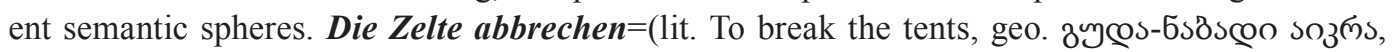
৪১Јও১लмm guda-nabadi aikra, gaetsalo = figurative meaning: to leave a place);

"Wie lange willst du in Prag bleiben? Oder hast du deine Zelte in Genf endgültig abgebrochen?" (Weiskopf-Inmitten des Stroms). (How long do you want to stay in Prague? Or did you finally break your tents in Geneva?).

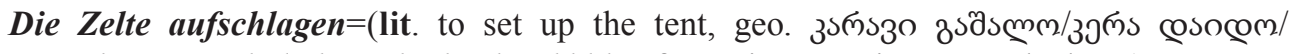
œusbbm@o karavi gashalo kera daido, dasakhlde= figurative meaning: to settle down).

...Dort will ich in Zukunft meine Zelte aufschlagen (Kellermann-Totentanz). (There I want to pitch my tents in the future).

In many cases it is impossible to determine the literary source, idiomatic phraseologisms originated from. We believe that a great number of Phraseology originated from Folklore. Such kind of idiomatic phraseologisms in German is:

"etwas (viel)auf dem Kerbholz haben"= (lit. to have some (many) marks on the label/name-

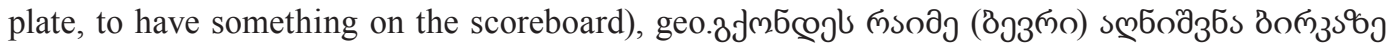
(bsfojby) gkondes raime aghnishvna birkaze. This idiomatic phraseologism reminds us the old custom - marking the debtors. Figuratively the expression means "to have sins". Georgian equivalents of the above mentioned German idiomatic phtaseology are: "6sbononbsfsdos" nakhshirna-

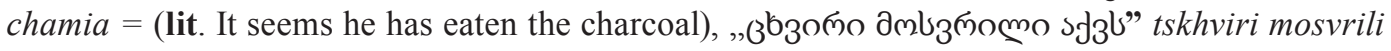
$a k v s=($ lit. He has a dirty nose).

...Der scheint auch etwas auf dem Kerbholz zu haben (12). (He also seems to have something on the scoreboard) [12].

The same can be said about German idiomatic phraseology, which is connected with the

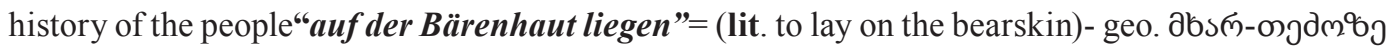
fsamf̧mms mkhartedzoze tsamotsola $=$ (lit.to lay on the shoulder) $=$ figurative meaning - to be lazy). The idiomatic phraseology goes back to the old tradition of German tribes and reflects their lifestyle. Old Germans' favourite activities were: hunting and going to the war, but in their free time, they did nothing. They used to lay on the bearskin, while women were busy with family and field work.

“Den ganzen Winter über lag er auf der Bärenhaut” [12] (All winter he was laying on the bearskin).

In Georgian there are some national-specific idiomatic phraseology that have a historical origin. One of them is " 3 şsl boco zsosms" kakas khidi gaiara (lit. to cross the bridge of Kaka) figurative meaning: "to disappear." The origin of the idiom is such: the captives, who were kidnapped from Western Georgia (namely from Imereti), were transported to Turkey through Kaka Bridge (The Kaka Bridge is located on the bank of the river Khaniistskali, coming from Parsati mountain.). The captive who had crossed the bridge was considered to be missing. Georgian idiomatic phraseology: "Rsomynnol fysmo cosmos" chailuris tsqali dalia (lit. drank water of Chailu- 
ri) has the same content and metaphorically means "to be lost.» This idiomatic phraseology like the previous one has an interesting historic origin (Later, the meaning of the idiom expanded, and now it is associated with somebody's death [13].

Except extra-linguistic factors, there are linguistic factors that affect the origin of Phraseology. Such phraseological units have structural-semantic equivalents in many languages. The phrases with the word «fire» give us just a basis of comparison of phraseologisms, because almost all phraseologisms with the word «fire» have structural equivalents (of form, meaning, and function) complete equivalents in both the source language and the target languages. Feuer (fire)- after Duden $=$ form of combustion with the flame formation, in which light and heat arise. Lexeme "Fire" appears in different phraseologisms: aus dem Feuer reißen $=($ lit.tear out of the fire $)=$ something

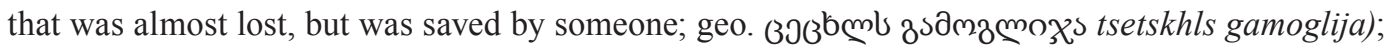
e. g. schließlich haben sie das Spiel doch noch aus dem Feuer gerissen (after all, they have finally ripped the game out of the fire);mit dem Feuer spielen = (lit. play with the fire =Recklessly disre-

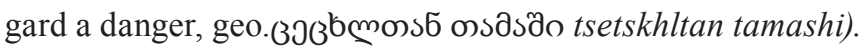

...Vor hundert Jahren konnte einer noch sagen,der Krieg sei die Fortsetzung der Politik. Wer heute mit dem Feuer spielt, riskiert den Untergang der ganzen Welt. (... [12] A hundred years ago one could say that the war was the continuation of politics. Those who play with fire today risk the downfall of the whole world).

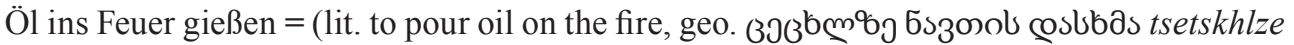
navtis daskhma, =figuratively 'to ignite the passions,' 'make things worse.'It is widely known that if someone pours oil on the fire, it flares. The same can be said about the arguments that can cause serious disputes. Consequently, the metaphorical idiom was generated by the frequent use of the expression.

...Hättest du dir diese häßliche Bemerkung nicht sparen können? Du hast damit nur Öl ins Feuer gegossen) (Did you not save this ugly remark? You only used it to pour oil into the fire) [14].

From the above mentioned examples it becomes clear that idiomatic phraseologisms are created on the basis of associations.

As we mentioned above, some idiomatic phraseologisms are characterized by national-specific characteristics. Idioms, connected with a national-specific situation, have no structural-semantic equivalents in other languages. For example, "ein X für ein U(vor) machen"= (lit. make an $\mathrm{X}$ for a $\mathrm{U}=$ figurative meaning: to mislead, to deceive); Georgian equivalent: oзs mo subzom tvali

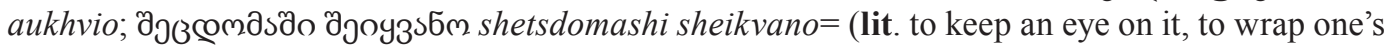
eye = figurative meaning: to mislead, to deceive);

Ja, mein lieber Herr Senator“, hatte Doktor Grabov gesagt, ,,... die Lungenentzündung ist nun doppelseitig, und das ist immer bedenklich, ich mache Ihnen kein X für ein U (Th. Mann-Buddenbr.).(«Yes, my dear senator», said Doctor Grabov, the pneumonia is now bilateral, and that's always worrying, I do not make you an $\boldsymbol{X}$ for a $\boldsymbol{U})$.

The national-specific idiom is German (bei jm.) Ist Hopfen und Malz verloren = (lit.hops and malt are lost= figuratively the idiom means "false, vain work."); geo. lit. b3os cos smsm

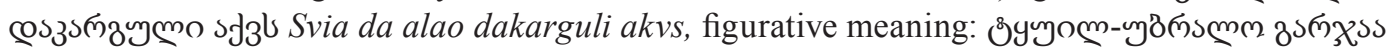
tkuilubralo garjaa.The history of the idiom goes back to the middle Ages. Since the middle Ages hops and malt have been used for the production of beer. If the composition of the mixture was wrong or the fermentation later failed, the basic substances themselves as well as the result were unusable.

...Es wurmte ihn, dass ihn Kohler für einen ansah, an dem Hopfen und Malz verloren ist (Segehrs-Die Rückkehr). (It hated him that Kohler saw him as one who lost hops and malt).

Examples of national-specific idioms are found even in Georgian, for example: "yyng 380 o bsbzo sm cosasłms" kurebze khakhvi ar damachra=(lit.do not cut the onions on the ears=figura-

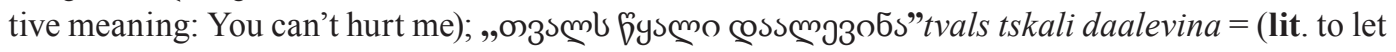
the eye drink water=figuratively: to be pleased by something or someone) [13].

Secondary ways of forming phraseological units are those when a phraseological unit is formed on the basis of another phraseological unit. They are: a) conversion, e. g. to vote with one's feet $\rightarrow$ vote with one's feet; b) changing grammar form, e. g. make hay while the sun shines $\rightarrow$ to 
make hay while the sun shines;c) borrowing phraseological units from other languages, either as translation loans, e. g. living space (German), to take the bull by the horns (Latin), etc.

One of the ways of forming a phraseological unit is lexical derivation. New phraseological unit can be derived from the already existing phraseologisms. For example, in German there was

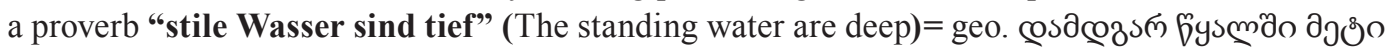

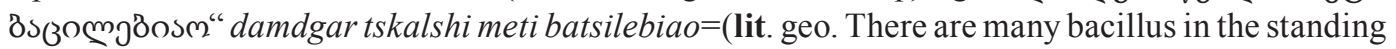
water, from which was born a new idiomatic phraseology "stiles Wasser" $=($ lit. standing water $)=$

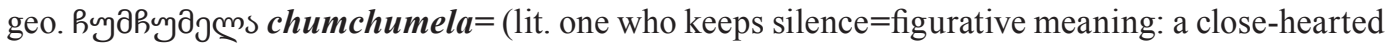
person, a person who dislikes intimacy, who keeps silence).

Kennen Sie den Herrn Roland? "-“ Ja, aber ich kann nicht viel über ihn sagen. Er ist ein stilles Wasser" [4] (Do you know Mr. Roland? “-” Yes, but I can not say much about him. He is a still water)» [14].

In German and Georgian languages there are idiomatic phraseology with unique components. They are often called as necrotisms. Necrotisms are not used independently in the language and can't give an idea about the modern world. For example, "Maulaffen feilhalten" (das Maul offenhalten, vor Staunen oder Neugier) = (lit. keep your mouth open (in amazement or curiosity);-

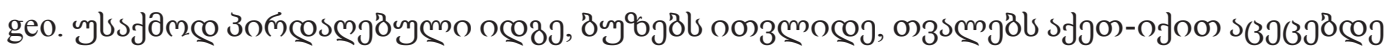
usaqmod pirdaghebuli idge, buzebs itvlide, tvekebs athethebde (lit.keep your mouths out, count the flies, to blink your eyes=figurative meaning: idly watch).

Was stehst du herum und hältst Maulaffen feil! (What's wrong with you? What are you standing around and blinking your eyes)? [12]

In Georgian there are idiomatic phraseologies with some incomprehensible components. Components of such idiomatic phraseologies are mainly of foreign origin, for example

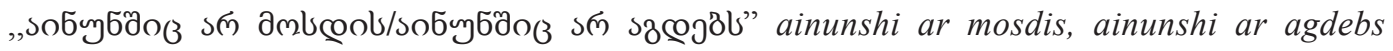
soby5 Ainun is the word of Arabic origin and means "an eye", figurative meaning= does not pay attention, does not care.

In German there is an idiomatic phraseology for it: "etw. auf die leichte Achsel nehmen"= (lit.to take something on the light arm-pits). It has the same meaning in Georgian, but it does not coincide with its counterpart structuraly and semantically.

"Gut, -sagte er, dass du es auf die leichte Achsel nimmst"(Goethe-Leiden des jungen Werters). (Good,» he said, "that you take it easy on the arm»).

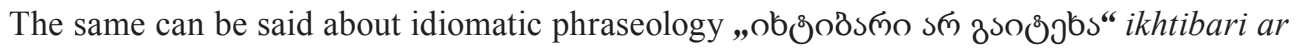
gaitekha. „obonsठs'ns” ikhtabara is the word of Arabic origin and means:"Experience”, "Stirring”, figurative meaning= He did not lose his hope, he did not break his heart [13].

Unmotivated idiomatic Phraseology can sometimes be explained by the etymological-historical analysis. It must be emphasized that the criterion of motivation is very subjective. It often depends on the level of culture and education of the speaker.

\section{Conclusion}

1. The analysis showed that phraseology is one of the most difficult lexico-grammatical and semantic linguistic formations and is one of the sources of vocabulary enrichment. It reflects the history of the nation, traditions and customs of different cultures.

2. The contrastive analysis of German and Georgian phraseologisms revealed that either whole or partial new understanding of free phrases is the most productive way to generate phraseological units. The second way to generate phraseological units is derivation, creation of new phraseological units from already existing phraseologism. Phraseological units, which have generated from the secondary phraseology, undergo two stages: the stage of potential phaseology and the stage of forming idiomatic phraseology.

3. Both contrastive-historical and contrastive-language language studies revealed that idiomatic phraseologisms have numerous multi-language characteristics, and peculiarities of idiom usage can be explained with the help of culture-specific factors.

4. Idiomatic phraseologisms, resulting from free syntactic units, show complete or partially complete equivalence relations (24, $10 \%$ of 40 idiomatic phraseologisms). No structural-semantic 
equivalence relationships are found in historical phraseology and in the idiomatic phraseology with unique components $(16,4 \%$ of 40$)$. However, it does not mean that they can't be translated. They are either translated by paraphrasing or by retaining the same meaning, but changing the form.

In all, we have studied 40 phraseological entities, most of which are idiomatic phraseologisms. The comparison of the phraseologisms of different cultures makes it clear that the complete correspondence between the components occurs not only in related, but also in unrelated languages.

\section{References}

[1] Burger, H., Buhofer, A., Sialm, A. (Eds.) (1982). Handbuch der Phraseologie. Berlin, New York: Walter de Gruyter, 448. doi: http://doi.org/10.1515/9783110849394

[2] Burger, H. (1973). Deutsche idiomatik. Tübingen: Niemeyer, 117.

[3] Busch, A., Stenschke, O. (2018). Germanistische Linguistik. Tübigen: Narr Francke Attempto Verlag GmbH+ Co.KG, 256.

[4] Binowitsch, L., Grischin, N. (1975). Deutsch-Russisches Phraseologisches Wörterbuch. Moscow: Verlag „Russische Sprache“, 656.

[5] Cooper, T. C. (1998). Teaching Idioms. Foreign Language Annals, 31 (2), 255-266. doi: http://doi.org/10.1111/j.1944-9720.1998. tb00572.x

[6] Drescher, M.; Sabban, A. (Ed.) (1997). Wie expressiv sind Phraseologismen? Phraseme im Text. Beiträge aus romanistischer Sicht. Bochum, 67-95.

[7] Fleischer, W. (1997). Phraseologie der deutschen Gegenwartssprache. Leipzig: Tübingen: Max Niemeyer, 302. doi: http:// doi.org/10.1515/9783110947625

[8] Römer, C., Brigitte, M. (2005). Lexikologie des Deutschen. Tübingen: Gunter Narr Verlag, 236.

[9] Sakhokia, T. (1979). Kartuli Khatovani sitqva tkmani. Tbilisi: Merani. Available at: https://sites.google.com/site/mygeolingua/ khatovani-sitqva-tkmani Last accessed: 19.09.2017

[10] Shakirova, T., Erenchinova, E. (2015). K voprosu o roli i spetsiphike phraseologii v pronstranstve iazikovoi kartini mira. Molodoi uchenyi, 3, 990-993.

[11] Deutsch-Georgisches Phraseologisches Wörterbuch (2010). Batumi: Shota Rustaveli State University.

[12] Stambolishvili, N. (2018): Linguistic origin of idioms F Strawlingist fibers. Interdisciplinaires en Sciences humaines (IISH), 5, 654-664. Available at: http://ojs.iliauni.edu.ge/index.php/eish/article/view/430/317

[13] Takaishvili, A. (1961). Qartuli Praseologiis sakitkhebi. Tbilisi.

[14] Vinogradov, V. (1996). Ob osnovnikh tipakh phraseologicheskikh edinits v russkom iazike. Sovremeni Ruski Iazik: Leksikologia, Leksigrafia. Moscow, 288. 